\title{
CVIR Special Issue on Radiation Protection
}

\author{
Werner R. Jaschke ${ }^{1}$
}

Received: 2 February 2021 / Accepted: 24 February 2021 / Published online: 17 March 2021

(c) The Author(s) 2021

Radiation-induced tissue reactions and malignant diseases were for a long time considered to be an issue of the past. However, with the introduction of CT and fluoroscopically guided interventions (FGI), nearly forgotten detriments of ionizing radiation have returned. In the 1990s, several authors reported skin injuries in patients undergoing fluoroscopyguided interventions, loss of hair following CT perfusion scans and neurointerventions [1]. Just recently, Li et al. [2] reported an alarmingly high effective dose in a significant number of patients who had one or more fluoroscopically guided interventional procedures. This calls for a change in the practice of interventional radiologists and endovascular therapists, otherwise we would be scrutinised by competent authorities and the public more and more. Since stochastic risks take several years to manifest, the connection between it and an intervention is no longer that apparent.

Smoking was for a long time an accepted habit, but it no longer is. Since a lot of data on negative health effects in smokers and people exposed to cigarette smoke was published, public opinion turned against it. This was only possible because awareness campaigns were successful and they gradually changed people's attitude towards smoking. Nowadays, smoking is banned in public places in most countries. Like raising attention about smoking, in interventional radiology we must continuously raise the awareness of radiation protection in patients and staff.

For years, CIRSE and its Radiation Protection Task Force have been campaigning to make interventional radiology a safe and well-accepted medical subspeciality. Since many interventional procedures involve use of ionizing radiation, CIRSE decided to focus not only on education on when and how to perform specific procedures, but also on radiation protection. Interventional radiologists are in the best position to promote radiation safety issues. But let's face it, despite training in radiology many of us sometimes forget, ignore or misinterpret radiation safety issues. This special issue with a collection of articles on radiation protection tries to provide essential information on how to handle radiation in order to make patients and operators safe from unjustified and unnecessary high doses of radiation. This special issue is one of many attempts to convey the message that $\mathrm{CT}$ and angiographic equipment may be potentially dangerous for patients and operators if not used appropriately. Together with the authors of the articles from the special section, I believe that radiation safety issues should not be simply delegated to medical physicists and technologists. Radiation safety issues should be handled by a radiation safety team that includes interventional radiologists, who should also have a thorough understanding of radiation hazards and how to prevent them.

So, next time before you start a procedure, remember that there is always an invisible companion with you: ionizing radiation. If you know how to measure and deal with it, both you and your patients will be safe. This special issue aims to provide useful information for your daily practice, because together we can keep interventional radiology safe and make radiation-induced tissue reactions a part of the past.

\footnotetext{
Werner R. Jaschke

werner.jaschke@i-med.ac.at

1 Department of Radiology, Medical University of Innsbruck, Anichstrasse 35, 6020 Innsbruck, Austria
} 
Funding This study was not supported by any funding.

\section{Compliance with Ethical Standards}

Conflict of interest The author declares that he has no conflict of interest.

Consent for Publication For this type of study consent for publication is not required.

Ethical Approval This article does not contain any studies with human participants or animals performed by the author.

Informed Consent For this type of study informed consent is not required.

Open Access This article is licensed under a Creative Commons Attribution 4.0 International License, which permits use, sharing, adaptation, distribution and reproduction in any medium or format, as long as you give appropriate credit to the original author(s) and the source, provide a link to the Creative Commons licence, and indicate if changes were made. The images or other third party material in this article are included in the article's Creative Commons licence, unless indicated otherwise in a credit line to the material. If material is not included in the article's Creative Commons licence and your intended use is not permitted by statutory regulation or exceeds the permitted use, you will need to obtain permission directly from the copyright holder. To view a copy of this licence, visit http://creativecommons.org/licenses/by/4.0/.

\section{References}

1. Stewart FA, Akleyev AV, Hauer-Jensen M, Hendry JH, Kleiman NJ, Macvittie TJ, et al. ICRP publication 118: ICRP statement on tissue reactions and early and late effects of radiation in normal tissues and organs-threshold doses for tissue reactions in a radiation protection context. Ann ICRP. 2012;41(1-2):1-322. https://doi.org/10.1016/j.icrp.2012.02.001.

2. Li X, Hirsch JA, Rehani MM, Ganguli S, Yang K, Liu B. Radiation effective dose above $100 \mathrm{mSv}$ from fluoroscopically guided intervention: frequency and patient medical condition. AJR Am J Roentgenol. 2020;215(2):433-40. https://doi.org/10.2214/ajr.19.22227.

Publisher's Note Springer Nature remains neutral with regard to jurisdictional claims in published maps and institutional affiliations. 